\title{
THE EFFECT OF TRAINING USAGE OF ELECTRIC MEASURING INSTRUMENTS TO STUDENT PERFORMANCE ASSESSMENT IN THE BASIC PHYSICS EXPERIMENT 2 COURSE
}

\author{
Ernidawati $^{1)}$, Dina Syaflita ${ }^{2)}$, Naila Fauza ${ }^{3)}$, Widodo Budi Kurniawan ${ }^{4)}$. \\ ${ }^{1,2,3)}$ Physics Education, University of Riau \\ ${ }^{4)}$ Physics, University of Bangka Belitung \\ e-mail: ernidawati@lecturer.unri.ac.id \\ dinasyaflita@yahoo.com \\ naila_fauza@lecturer.unri.ac.id
}

\begin{abstract}
Experimental activities are closely related to measurement activities that require measuring instruments. Skills using measuring instruments affect learning outcomes of the experimental activities carried out. The purpose of this research was to determine the effect of the implementation of the training on the use of electrical measuring instruments on the performance evaluation of physics education students in the basic physics experiments 2 course. This type of research is survey research. The research population was all students of the Physics Education Study Program Universiti of Riau semester 2, who took the Basic Physics Experiment 2 course in 2017, 2018 and 2019. The number of classes was 6 classes and each year a random sample class was taken, so the research sample amounted 3 classes. For 2017 students taking part in the Basic Physics Experiment 2 course, were only given instructions on the use of measuring instruments when conducting experiments, where as in 2018 and 2019, students taking basic physics experiments 2 were provided with special training before conducting experiments. The data collection instrument used was from the results of a three-year student performance assessment sheet on the topic of multiloop and alternating current experiments. The data analysis technique used is descriptive analysis. The results showed that students who were equipped with training in the use of electric measuring instrument before the lecture begins of Basic Physics Experiment 2, gave better performance assessment results compared to students who were not equipped with training in using electric measuring instrument. Therefore, training in the use of measuring instruments before conducting an experiment is very important given the basic physics experiment 2 on the topic of multiloops and alternating current.
\end{abstract}

Keywords: electric measuring instruments, performance assessment, basic physics experiment 2. 


\title{
PENGARUH PELATIHAN PENGGUNAAN ALAT UKUR LISTRIK TERHADAP PENILAIAN KINERJA MAHASISWA PADA MATA KULIAH EKSPERIMEN FISIKA DASAR 2
}

\author{
Ernidawati $^{1)}$, Dina Syaflita ${ }^{2)}$, Naila Fauza ${ }^{3)}$, Widodo Budi Kurniawan ${ }^{4)}$. \\ ${ }_{1,2,3)}$ Pendidikan Fisika, Universitas Riau \\ ${ }^{4)}$ Fisika, Universitas Bangka Belitung
}

\begin{abstract}
Abstrak
Kegiatan eksperimen sangat berhubungan dengan kegiatan pengukuran yang memerlukan alat ukur. Keterampilan menggunakan alat ukur mempengaruhi capaian pembelajaran dari kegiatan eksperimen yang dilaksanakan. Tujuan penelitian ini adalah untuk mengetahui pengaruh pelaksanaan pelatihan penggunaan alat ukur listrik terhadap penilaian kinerja mahasiswa pendidikan fisika pada mata kuliah Eksperimen Fisika Dasar 2. Jenis penelitian ini adalah penelitian survey. Populasi penelitian adalah semua mahasiswa program studi pendidikan Fisika Universitas Riau semester 2 yang mengambil mata kuliah Eksperimen Fisika Dasar 2 pada tahun 2017, tahun 2018 dan tahun 2019. Jumlah kelas sebanyak 6 kelas dan setiap tahunnya diambil satu kelas sampel secara random, sehingga sampel penelitian berjumlah 3 kelas. Untuk tahun 2017 mahasiswa dalam mengikuti perkuliahan Eksperimen Fisika Dasar 2, hanya diberi petunjuk penggunaan alat ukur saat melakukan eksperimen, sedangkan pada tahun 2018 dan tahun 2019, mahasiswa yang mengambil eksperimen fisika dasar 2 dibekali dengan pelatihan khusus sebelum melakukan eksperimen. Instrumen pengumpul data yang digunakan adalah dari hasil lembar penilaian kinerja mahasiswa selama tiga tahun pada topik eksperimen multiloop dan arus bolak balik. Teknik analisis data yang digunakan adalah analisis deskriptif. Hasil penelitian menunjukkan, bahwa mahasiswa yang dibekali dengan pelatihan penggunaan alat ukur listrik sebelum dimulainya perkuliahan Eksperimen Fisika Dasar 2, memberikan hasil penilaian kinerja yang lebih baik dibanding dengan mahasiswa yang tidak dibekali dengan pelatihan penggunaan alat ukur listrik. Oleh karena itu, pelatihan penggunaan alat ukur sebelum melakukan eksperimen merupakan suatu hal yang sangat penting diberikan dakam eksperimen fisika dasar 2 pada topik multiloop dan arus bolak-balik.
\end{abstract}

Kata kunci: alat ukur listrik, penilaian kinerja, eksperimen fisika dasar 2

\section{Pendahuluan}

Mata kuliah eksperimen merupakan mata kuliah yang bertujuan untuk memberikan pengalaman langsung kepada mahasiswa untuk mengamati dan mempelajari fenomena alam mulai dari yang dapat diamati dalam kehidupan sehari-hari hingga yang hanya dapat diamati melalui kegiatan di laboratorium. Kegiatan eksperimen bermanfaat untuk membuktikan teori-teori fisika dan menemukan teori baru. Menurut Riyanto (2016), kegiatan eksperimen dilakukan untuk pengembangan konsep, mengatasi miskonsepsi, melatih keterampilan proses, dan melatih keterampilan menggunakan alat ukur. Menurut Sani (2012), eksperimen bertujuan untuk verifikasi teori yang sudah ada, mencari dan menentukan konstanta fisika.

Kegiatan eksperimen merupakan suatu kegiatan yang memungkinkan peserta didik untuk mengembangkan keterampilan proses sains dan sikap ilmiah (Subiantoro, 2010). Kegiatan eksperimen melatih mahasiswa untuk berpikir ilmiah dan memecahkan masalah melalui metode ilmiah (Riyanto, 2016). Selain itu, metode eksperimen dapat menurunkan miskonsepsi peserta didik terhadap suatu materi dan meningkatkan minat peserta didik (Zulvita \& Halim, 2017; Tarmizi, et al., 2017b). Melalui eksperimen, peserta didik memperoleh ilmu dan pemahaman baru (Yanti, et al., 2016) dan dapat meningkatkan kemampuan menyimpulkan dan mengkomunikasikan (Kurniato \& Dwijananti, 2010). Oleh karena itu, teori pada yang diperoleh mahasiswa dalam mata kuliah Fisika Dasar memang semestinya dipraktekkan melalui kegiatan eksperimen.

Kegiatan eksperimen berhubungan dengan kegiatan pengukuran. Pengukuran itu sendiri akan melibatkan alat ukur. Peserta didik memerlukan keterampilan menggunakan alat ukur dalam melaksanakan eksperimen 
(Djonoputro dalam Riyanto, 2016).

Keterampilan menggunakan alat ukur merupakan keterampilan penting dalam eksperimen terutama untuk alat ukur analog. Tanpa keterampilan ini kegiatan eksperimen tidak akan memberikan hasil yang diharapkan (Tarmizi, et al., 2017a).

Eksperimen yang berhubungan dengan kelistrikan merupakan salah satu eksperimen yang memerlukan banyak alat ukur seperti multimeter, amperemeter, voltmeter, basic meter, osiloskop, dan lainnya. Alat ukur dalam analog memerlukan keterampilan membaca alat. Tidak terampilnya mahasiswa dalam menggunakan alat ukur ini dapat menjadi kendala dalam melaksanakan kegiatan eksperimen karena mahasiswa menjadi kesusahan dalam mengambil data. Menurut Safriana (2017) keterampilan menggunakan alat ukur merupakan salah satu indikator penilaian psikomotorik mahasiswa dalam melakukan eksperimen.

Kesalahan pengukuran yang dilakukan akan mempengaruhi kegiatan eksperimen dan kesimpulan yang diperoleh dari kegiatan eksperimen. Kesalahan pengukuran bahkan ini juga dapat mengakibatkan eksperimen menjadi tidak dapat dilanjutkan (Riyanto, 2016; Handhika, 2012). Penelitian Masrian et al. (2014) menunjukkan bahwa kesalahan dalam penggunaan alat ukur listrik yang paling banyak dilakukan oleh peserta didik adalah kesalahan membaca skala alat ukur. Kesalahan ini berakibat pada kesimpulan kegiatan eksperimen yang diperoleh.

Pentingnya kemampuan membaca alat ukur listrik tidak hanya berpengaruh pada mata kuliah Eksperimen Fisika Dasar 2 saja. Lebih lanjut, keterampilan ini juga mempengaruhi capaian mata kuliah lanjutan, misalnya mata kuliah Eksperimen Elektronika, Instrumentasi, dan Eksperimen Fisika Sekolah 2. Mata kuliah ini sarat akan kegiatan pengukuran menggunakan alat ukur listrik. Dengan demikian, rendahnya keterampilan menggunakan alat ukur mahasiswa tidak hanya berdampak pada mata kuliah dasar saja, tetapi juga berdampak pada mata kuliah lanjutan yang kegiatan perkuliahannya juga menggunakan alat ukur yang sama.

Permasalahan yang ditemukan dalam perkuliahan Fisika Dasar II pada tahun 2017 adalah sebagian besar mahasiswa yang mengambil mata kuliah ini kesulitan dalam melaksanakan kegiatan eksperimen menggunakan alat ukur listrik padahal saat pengambilan data mahasiswa diajarkan bagaimana cara menggunakan alat ukur yang akan digunakan. Hal ini didukung melalui hasil capaian penilaian kinerja yang belum memuaskan. Penyebabnya adalah karena kurang terampilnya mahasiswa dalam menggunakan alat ukur listrik. Hal ini mengindikasikan, bahwa pemberian pengajaran cara menggunakan alat ukur listrik pada saat melakukan eksperimen saja tidak efektif meningkatkan keterampilan mahasiswa dalam menggunakan alat ukur listrik.

Salah satu solusi yang dapat digunakan untuk mengatasi permasalahan ini adalah dengan memberikan pelatihan tambahan berupa pelatihan menggunakan alat-alat ukur listrik. Selama satu pertemuan itu mahasiswa dilatih menggunakan dan membaca berbagai alat ukur listrik seperti multimeter, amperemeter, volt meter, basic meter dan osiloskop. Tidak ada kegiatan lain selama pelatihan ini melainkan hanya kegiatan menggunakan dan membaca alat ukur. Pelatihan ini bersifat tambahan, dan saat melaksanakan kegiatan eksperimen mahasiswa tetap diingatkan cara menggunakan alat ukur listrik.

Penelitian sebelumnya yang dilakukan oleh Sakti (2011) berfokus kepada hubungan pengetahuan alat ukur eksperimen dengan kemampuan psikomotorik pada eksperimen Fisika di SMA. Penelitian ini menggunakan soal tes untuk menguji pengetahuan alat ukur peserta didik. Selain itu, Safriana (2017) juga telah melakukan penelitian tentang pengaruh kemampuan menggunakan alat ukur terhadap kemampuan psikomotorik mahasiswa pada mata kuliah Elektronika Dasar 1. Penelitian ini melibatkan mahasiswa angkatan 2015 dengan instrumen berupa lembar observasi.

Perbedaan penelitian ini dengan penelitian sebelumnya adalah penelitian ini lebih berfokus pada pengaruh pemberian perlakuan tertentu berupa pelatihan khusus penggunaan alat ukur listrik terhadap hasil penilaian kinerja mahasiswa. Penelitian ini melibatkan mahasiswa tiga angkatan yang mengambil mata kuliah Ekperimen Fisika Dasar 2. Penelitian ini melibatkan tiga kelas berbeda pada tahun yang berbeda pula dengan materi yang sama. Semua mahasiswa tiap 
angkatan diberikan bekal penggunaan alat ukur hanya saja pada tahun 2018 dan 2019 ada penambahan berupa pelatihan penggunaan alat ukur yang dilaksanakan pada hari berbeda dengan hari dilaksanakannya perkuliahan eksperimen. Penelitian ini menarik dikaji untuk mengetahui pengaruh antara pelatihan penggunaan alat ukur listrik yang diberikan terhadap penilaian kinerja mahasiswa pada mata kuliah Eksperimen Fisika Dasar 2.

\section{Bahan dan Metode}

Jenis penelitian ini adalah penelitian Survey. Penelitian survey ini merupakan penelitian yang mengumpulkan data pada saat tertentu yang tidak melakukan perubahan terhadap variabel-variabel yang dikaji (Sugiono, 2012). Tujuannya untuk mendeskripsikan keadaan adanya pengaruh terhadap keadaan tertentu yang sudah berlaku terhadap sampel penelitian. Penelitian survey yang dimaksud untuk mengetahui ada tidaknya pengaruh pemberian pelatihan pada sample yang dikaji, dengan cara membandingkan satu atau lebih kelompok yang sudah mengalami perlakuan tertentu (Suharsimi Arikunto, 2000). Perlakuan yang telah diberikan berupa pemberian pelatihan langsung saat melakukan eksperimen dan pemberian pelatihan tambahan (khusus) terkait penggunaan alat-alat ukur listrik sebelum melakukan eksperimen.

Populasi penelitian ini adalah semua mahasiswa semester 2 yang mengambil mata kuliah Ekperimen Fisika Dasar 2 dari tahun 2017 sampai tahun 2019, sedangkan sampel penelitian ini adalah dari satu kelas mahasiswa pendidikan Fisika FKIP UNRI yang mengambil mata kuliah Eksperimen Fisika Dasar 2 dalam tiga tahun ajaran yaitu tahun 2017, tahun 2018, dan tahun 2019. Kelas yang menjadi sampel dipilih secara random dengan cara diundi. Penelitian ini dilaksanakan di Laboratorium Pendidikan Fisika FKIP Universitas Riau. Materi Eksperimen yang disurvey pada penelitian ini adalah materi kelistrikan terkait topik eksperimen multiloop dan arus bolak balik.

Mahasiswa yang mengambil mata kuliah Ekperimen Fisika Dasar 2 ditahun 2017 tidak mendapatkan pelatihan khusus menggunakan alat ukur listrik. Mereka hanya diajarkan cara menggunakan alat ukur listrik pada saat eksperimen berlangsung. Mahasiswa pada tahun 2018 dan 2019, terlebih dahulu dibekali dengan pelatihan penggunaan alat ukur sebelum perkuliahan Eksperimen Fisika Dasar 2 dimulai. Mahasiswa diberikan waktu khusus satu pertemuan untuk latihan penggunaan alat ukur listrik seperti multimeter, voltmeter, ampermeter, basic meter dan osiloskop, serta diajarkan cara membaca hasil pengukuran dan menentukan ketakpastian dalam pengukuran. Pelatihan ini menambah jam kuliah Eksperimen Fisika Dasar 2.

Instrumen pengumpul data yang digunakan adalah hasil lembar penilaian kinerja pada eksperimen multiloop dan arus bolak balik selama tiga tahun. Penyajian hasil penelitian dilakukan menggunakan grafik capaian penilaian kinerja pada tahun 2017, 2018, dan 2019. Teknik analisis data yang digunakan adalah analisis deskriptif.

\section{Hasil dan Pembahasan}

Pengambilan data penelitian ini telah dilakukan selama tiga tahun yaitu tahun 2017, 2018, dan tahun 2019. Untuk angkatan tahun 2017 mahasiswa tidak dibekali pelatihan penggunaan alat ukur listrik, cara penggunaan alat ukur listrik diajarkan pada saat perkuliahan Eksperimen Fisika Dasar 2 berlangsung saja. Akan tetapi, pada tahun 2018 dan 2019 mahasiswa dibekali dengan pelatihan khusus penggunaan alat ukur listrik terlebih dahulu. Hasil penilaian kinerja mahasiswa pada eksperimen multiloop ditampilkan pada Gambar 1.

Gambar 1 menunjukkan grafik penilaian kinerja mahasiswa dalam tiga tahun berturutturut pada eksperimen multiloop. Grafik Tahun Ajaran 2017 yang ditunjukkan oleh warna biru adalah capaian hasil belajar peserta didik tanpa dibekali pelatihan khusus menggunakan alat ukur listrik. Sedangkan grafik tahun 2018 dan 2019 yang ditunjukkan oleh warna merah dan hijau adalah penilaian kinerja mahasiswa yang dibekali dengan pelatihan khusus menggunakan alat ukur listrik. 


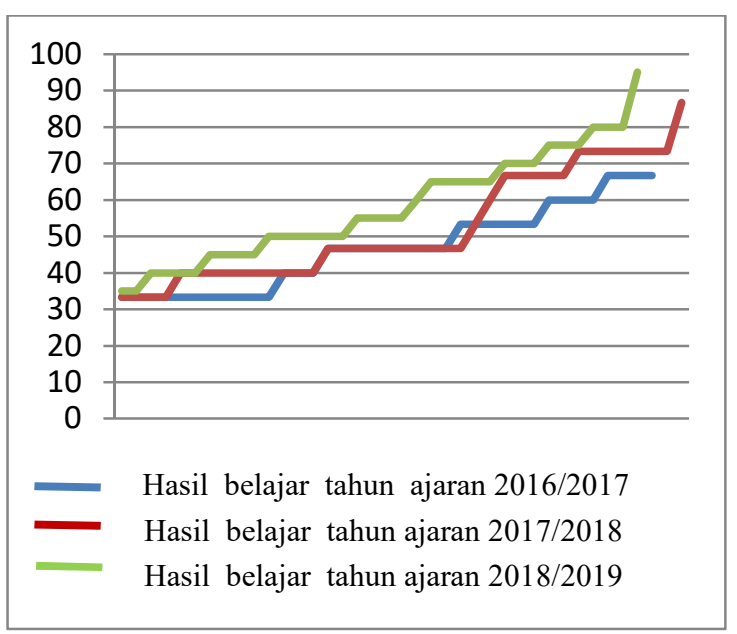

Gambar 1. Grafik penilaian kinerja eksperimen multiloop.

Gambar 1 memperlihatkan bahwa penilaian kinerja mahasiswa pada eksperimen multiloop yang dibekali dengan pelatihan khusus sebelum perkuliahan lebih baik dibandingkan mahasiswa yang tidak dibekali pelatihan alat ukur listrik. Pada tahun 2017, nilai terendah yang diperoleh mahasiswa adalah 33,3 dan nilai tertingginya adalah 66,7 dengan nilai rata-rata 46,84. Pada tahun 2018, nilai terendah adalah 33,3 dan nilai tertinggi adalah 86,7 dengan rata-rata 52,81. Untuk tahun 2019 , nilai terendah adalah 35 dan nilai tertinggi adalah 95 dan nilai rata-ratanya adalah 57,92 . Hal ini menunjukkan bahwa rata-rata hasil penilaian kinerja mahasiswa semakin membaik. Peserta pada tahun 2018 dan 2019 rata-rata penilaian kinerja mahasiswa pada mata kuliah Eksperimen Fisika Dasar 2 materi multiloop berada di atas 50. Grafik jabaran nilai kinerja mahasiswa untuk materi multiloop ditunjukkan pada Gambar 2.

Gambar 2 menunjukkan bahwa pada tahun 2019 terjadi pengurangan jumlah mahasiswa yang memiliki rentang nilai 20,1-40, berdasarkan data yang ditunjukkan oleh diagram berwarna biru (warna paling bawah), sedangkan untuk nilai 60,1-80 yang ditampilkan melalui diagram berwarna hijau (warna ketiga dari bawah) terjadi peningkatan. Ini artinya pada tahun 2018 dan 2019 terjadi peningkatan jumlah mahasiswa yang memiliki rentang nilai 60,1-80. Tahun 2019 ada mahasiswa yang nilainya berada di atas 80 sesuai warna ungu (warna keempat dari bawah). Dengan demikian, penelitian ini memberikan hasil bahwa penambahan pelatihan penggunaan alat ukur listrik memberikan hasil penilaian kinerja yang lebih baik dibanding yang tidak diberi pelatihan khusus.

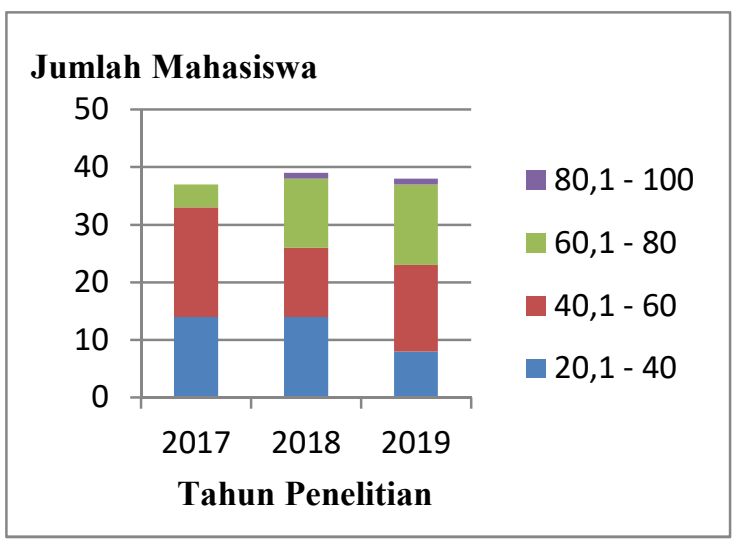

Gambar 2. Grafik jabaran penilaian kinerja eksperimen multiloop.

Rustam dalam Riyanto (2016) mengemukakan bahwa kegiatan eksperimen dapat meningkatkan motivasi, mengembangkan keterampilan dasar, dan menunjang materi/konsep tertentu. Hal ini sejalan dengan hasil penelitian Subekti \& Ariswan (2016) tentang pembelajaran Fisika menggunakan metode eksperimen. Hasil penelitian ini menunjukkan bahwa pembelajaran fisika dengan metode eksperimen dapat meningkatkan aspek kognitif dan keterampilan proses sains. Hasil penilaian kinerja mahasiswa pada mata kuliah Eksperimen Fisika Dasar 2 dalam tahun 2018 dan 2019 menunjukkan nilai yang tidak jauh berbeda. Hal ini menunjukkan konsistensi hasil yang diberikan melalui pelatihan tambahan mengenai penggunaan alat ukur listrik yang dilakukan sebelum perkuliahan eksperimen.

Hasil penilaian kinerja mahasiwa pada eksperimen arus bolak balik ditampilkan melalui Gambar 3. Gambar 3 memperlihatkan penilaian kinerja mahasiswa pada eksperimen arus bolak balik selama tiga tahun. Hasil yang diperoleh pada tahun 2018 dan 2019 menunjukkan hasil yang lebih tinggi daripada hasil capaian tahun 2017. Hal ini ditandai oleh semakin naiknya nilai eksperimen mahasiswa. Tahun 2017, ada mahasiswa yang memiliki nilai terendah sebesar 26,7, sedangkan pada tahun 2018 dan 2019 nilai terendah mahasiswa lebih tinggi yaitu 33,3 dan 40. 


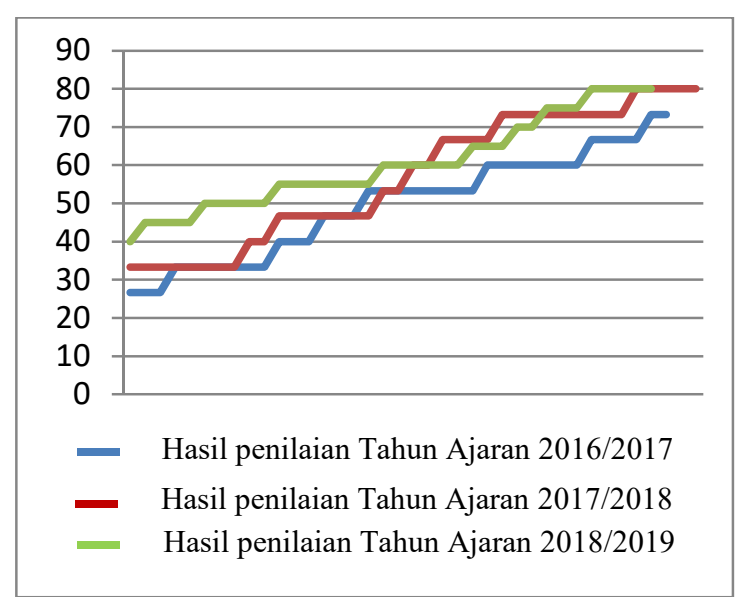

Gambar 3. Grafik penilaian kinerja eksperimen arus bolak balik.

Rata-rata penilaian kinerja mahasiswa juga semakin naik. Tahun 2017, nilai terendah adalah 26,7 dan nilai tertinggi adalah 73,3 dengan ratarata 49,54. Tahun 2018 nilai terendahnya adalah 33,3 dan nilai tertingginya adalah 80 dengan rata-rata 57,26, sedangkan pada tahun 2019, nilai terendah adalah 40 dan nilai tertinggi adalah 80 dengan rata-rata 60,42 . Hal ini disebabkan adanya pelaksanaan pelatihan penggunaan alat ukur listrik sebelum perkuliahan eksperimen. Nilai tahun 2019 lebih tinggi daripada tahun 2018, hal ini disebabkan karena alat ukur listrik yang digunakan selama pelatihan lebih bervariasi daripada pada tahun 2018. Jabaran penilaian kinerja mahasiswa pada materi arus bolak balik ditampilkan melalui Gambar 4.

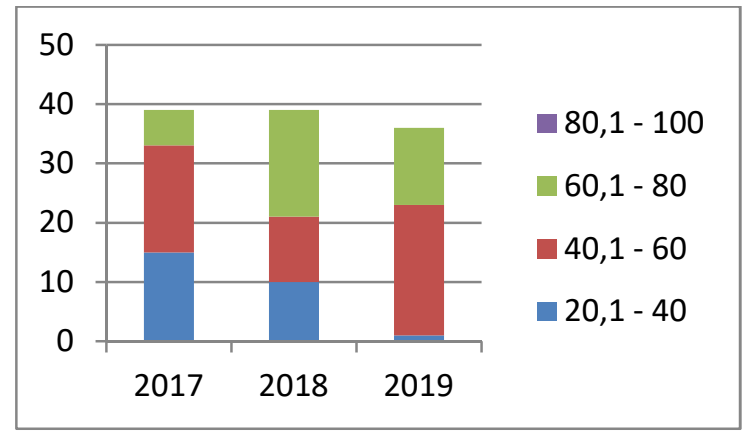

Gambar 4. Grafik jabaran penilaian kinerja eksperimen arus bolak balik.

Gambar 4 menunjukkan bahwa setiap tahun mahasiswa yang mendapat nilai 20,1-40 semakin kecil. Pada tahun 2017, mahasiswa yang mendapat nilai di atas 60 sebanyak $(16,22 \%)$. Tahun 2018, mahasiswa yang mendapat nilai di atas 60 sebanyak $(46,15 \%)$, sedangkan pada tahun 2019, mahasiswa yang mendapat nilai di atas 60 sebanyak $(36,11 \%)$. Tahun 2019 terjadi pengurangan jumlah mahasiswa yang mendapat nilai di atas 60 dari tahun sebelumnya. Hal ini, disebabkan pada tahun 2019 penggunan alat ukur listrik yang digunakan selama pelatihan lebih bervariasi daripada pada tahun 2018.

Pelaksanaan pelatihan penggunaan alat ukur listrik sebelum perkuliahan eksperimen berdampak kepada peningkatan penilaian kinerja mahasiswa. Pelaksanaan pelatihan ini dapat meningkatkan kemampuan mahasiswa menggunakan alat ukur. Peningkatan kemampuan mahasiswa dalam menggunakan alat ukur yang berdampak pada penilaian kinerja mahasiswa dalam melakukan kegiatan eksperimen. Hasil penelitian ini sejalan dengan hasil penelitian Safriana (2017) yang menunjukkan bahwa nilai psikomotorik (keterampilan) mahasiswa dalam bereksperimen dipengaruhi juga oleh kemampuan mahasiswa dalam menggunakan alat-alat ukur. Selain itu, Riyanto (2016) dan Andiasari (2015) mendapatkan bahwa kemampuan menggunakan alat ukur mempengaruhi kegiatan eksperimen, karena tingginya tingkat kesalahan dalam melakukan eksperimen, yang umumnya disebabkan oleh ketidaktahuan mahasiswa tentang fungsi dan penggunaan alat ukur.

Pelatihan penggunaan alat ukur sebaiknya memang perlu diberikan sebelum mahasiswa memulai perkuliahan Eksperimen Fisika Dasar 2. Hal ini disebabkan karena mahasiswa yang mengambil mata kuliah ini sebagian besar adalah mahasiswa semester 2 yang belum tentu di jenjang pendidikan SMA mereka mendapatan pengalaman mengoperasikan dan membaca alat ukur listrik. Bilamana mahasiswa tidak terampil menggunakan alat ukur listrik, maka ini juga akan berdampak pada mata kuliah listrik lanjutan seperti Eksperimen Elektronika, Instrumentasi dan Eksperimen Fisika Sekolah 2. Hal ini sejalan dengan hasil penelitian Sakti (2011) yang menunjukkan bahwa siswa yang memiliki pengetahuan tentang alat eksperimen yang baik memiliki kemampuan psikomotorik yang baik.

Kendala yang masih dihadapi selama penelitian adalah keterbatasan jumlah alat eksperimen yang tersedia. Satu alat digunakan oleh 3-4 orang mahasiswa. Hal ini dapat menyebabkan ada mahasiswa yang mendapat 
kesempatan menggunakan lebih lama dan ada yang tidak. Selain itu, variasi alat yang tersedia juga mempengaruhi kemampuan mahasiswa dalam melakukan eksperimen Fisika Dasar 2.

\section{Kesimpulan dan Saran}

Berdasarkan hasil penelitian survey yang dilakukan, pelatihan penggunaan alat ukur listrik memberikan pengaruh yang positif terhadap hasil penilaian kinerja mahasiswa dalam Eksperimen Fisika Dasar 2. Hasil penilaian kinerja lebih baik apabila sebelum perkuliahan, mahasiswa dibekali dengan pelatihan khusus penggunaan alat ukur listrik dibandingkan dengan hasil penilaian kinerja yang tidak dibekali pelatihan sebelum perkuliahan.

Dengan demikian direkomendasikan untuk memberikan pelatihan penggunaan alat ukur terlebih dahulu, sebelum memulai perkuliahan Eksperimen Fisika Dasar 2, karena mahasiswa yang mengambil mata kuliah ini adalah mahasiswa baru yang belum tentu mendapatkan pengalaman menggunakan alat ukur di jenjang sekolah menengah. Pelatihan yang dilakukan sebaiknya menggunakan jumlah alat yang memadai dan bervariasi.

\section{Daftar Pustaka}

Andiasari, L., 2015. Penggunaan Model Inquiry dengan Metode Eksperimen dalam Pembelajaran IPA di SMPN 10 Probolinggo. Jurnal Kebijakan dan Pengembangan Pendidikan, 3(1).

Handhika, J., 2012. Pembelajaran Fisika Melalui Inkuiri Terbimbing dengan Metode Eksperimen dan Demonstrasi Ditinjau dari Aktivitas dan Perhatian Mahasiswa. Jurnal Penelitian Pembelajaran Fisika, 1(1).

Kurnianto, P., \& Dwijananti, P., 2010. Pengembangan Kemampuan Menyimpulkan dan Mengkomunikasikan Konsep Fisika Melalui Kegiatan Eksperimen Fisika Sederhana.Jurnal Pendidikan Fisika Indonesia, 6(1).

Masrian, Sahala, S., \& Hamdani. 2014. Deskripsi Kesalahan Siswa Menggunakan Multimeter Analog pada Materi Alat Ukur Listrik di SMA.
Jurnal Pendidikan dan Pembelajaran Khatulistiwa, 3(9).

Riyanto, E., 2016. Identifikasi Kesalahan Mahasiswa dalam Melaksanakan Eksperimen pada Mata Kuliah Konsep IPA 2 di Prodi PGSD FIP IKIP PGRI Madiun. Premiere Educandum: Jurnal Pendidikan Dasar dan Pembelajaran, 2(02).

Safriana, S., 2017. Pengaruh Kemampuan Penggunaan Alat Ukur Listrik Terhadap Kemampuan Psikomotorik Mahasiswa pada Eksperimen Elektronika Dasar. Jurnal Dedikasi Pendidikan, 1(2): pp.124-130.

Sakti, I., 2011. Korelasi Pengetahuan Alat Eksperimen Fisika dengan Kemampuan Psikomotorik Siswa di SMA Negeri q Kota Bengkulu. EXACTA, 9(1): 67-76.

Sani, R. A. 2012. Pengembangan Laboratorium Fisika. Unimed Press, Medan.

Subekti, Y., \& Ariswan, A., 2016. Pembelajaran Fisika dengan Metode Eksperimen untuk Meningkatkan Hasil Belajar Kognitif dan Keterampilan Proses Sains. Jurnal Inovasi Pendidikan IPA, 2(2): pp. 261.

Subiantoro, A. W., 2010. Pentingnya Eksperimen dalam Pembelajaran IPA. Universitas Negeri Yogyakarta, Yogyakarta.

Sugiyono. 2010. Metode Penelitian Pendidikan Pendekatan Kuantitatif, Kualitatif, dan $R \quad \& \quad D$. Alfabeta, Bandung.

Suharsimi Arikunto, 2000. Manajemen Penelitian. Rineka, Jakarta.

Tarmizi, T., Halim, A., \& Khaldun, I., 2017a. Penggunaan Metode Eksperimen untuk Mengatasi Miskonsepsi dan Meningkatkan Minat Belajar Peserta Didik pada Materi Rangkaian Listrik di SMA Negeri 1 Jaya Kabupaten Aceh Jaya. JIPI (Jurnal IPA \& Pembelajaran IPA), 1(2): 149-158.

Tarmizi, T., Halim, A., \& Khaldun, I. 2017b. Penggunaan Metode Eksperimen untuk Mengatasi Miskonsepsi dan Meningkatkan Pemahaman Konsep Materi Rangkaian Listrik di SMA Negeri 1 Jaya Kabupaten Aceh Jaya, Aceh. Jurnal Pendidikan Sains Indonesia (Indonesian 
118 Jurnal Geliga Sains (JGS): Jurnal Pendidikan Fisika, 7(2): 111-118, 2019

Journal of Science Education), 5(1): 511.

Yanti, D. E. B., Subiki, S., \& Yushardi, Y., 2017. Analisis Sarana Prasarana Laboratorium Fisika dan Intensitas Kegiatan Eksperimen Fisika dalam Mendukung Pelaksanaan Pembelajaran Fisika SMA Negeri di Kabupaten
Jember. Jurnal Pembelajaran Fisika, 5(1): 41-46.

Zulvita, R., \& Halim, A., 2017. Identifikasi dan Remediasi Miskonsepsi Konsep Hukum Newton dengan Menggunakan Metode Eksperimen di Man Darussalam. Jurnal Ilmiah Mahasiswa Pendidikan Fisika, 2(1): 128-134. 